\title{
The role of mitochondrial genome (mtDNA) in somatic and embryo cloning of mammals. A review
}

\author{
M. Samiec \\ National Research Institute of Animal Production, \\ Department of Animal Reproduction Biotechnology \\ 32-083 Balice, Poland
}

(Received 22 April 2004; revised version 5 January 2005; accepted 18 March 2005)

\begin{abstract}
Mitochondria are semiautonomous organelles that contain double-stranded ( $\alpha$-helix) circular DNA molecules (mtDNAs) of about 16300 to 16500 base pairs (bp). The mtDNA encodes only 13 proteins, 22 tRNAs and 2 rRNAs. Up to $95 \%$ of proteins involved in biogenesis and functions of mitochondria are encoded by the cell nucleus. The copy number of mitochondrial genome in a typical mammalian somatic cell ranges from approximately $2 \times 10^{3}$ to about $5 \times 10^{3}$, whereas the number of mtDNA molecules in a single mature (Metaphase II) oocyte is about $1.6 \times 10^{5}$ in mice, $2.5 \times 10^{5}$ in cattle and 3-8 $\times 10^{5}$ in humans. In the procedure of somatic or embryo cell cloning (nuclear transfer), mitochondria of nuclear donor cells, together with the nucleus, are transplanted to the enucleated recipient oocyte (ooplast). Thus, the cloned embryo should harbour the mtDNAs from both the donor cell and the recipient oocyte. In cloned animals, mitochondria are inherited primarily from recipient oocytes, and mitochondria from donor cells appear to be rapidly eliminated during the first few cleavage divisions and are almost undetectable by the blastocyst stage. This selective segregation of the donor mitochondrial genome, which takes place in the preimplantation development of nuclear transfer-derived embryos, leads gradually to cellular mtDNA homoplasmy. Only in some cases does the mitochondria originating from both donor cells and recipient oocytes coexist (the so-called mtDNA heteroplasmy). When cloning both embryos and adult individuals, what is often forgotten is the presence in the cytoplasm of donor- and recipient-cells of mtDNA. This contains small (approximately $0.01 \%$ ) amounts of total cell genetic information, but it is different from information recorded in the nuclear DNA ( $99.99 \%$ of cellular genome). Thus, introduction of donor cell nucleus into the oocyte derived from another individual leads to generation of hybridic (in terms of genetic mitochondrial material) reconstructed oocytes, which can have a certain influence on the genotype and phenotype identity of offspring produced as a result of cloning. The "ideal" clone can be obtained only with donor cell nucleus transplanted into the oocyte originating
\end{abstract}

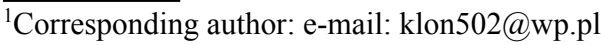


from the same individual. Therefore "ideal mammalian clones" can only be the clones of females, whose overall mitochondrial genome has a completely homogenouspattern of regulatory and coding nucleotide sequences of all cellular mtDNA copies in all the somatic and germ cell lines.

KEY WORDS: mitochondrial DNA, D-loop, cloning, nuclear transfer, homoplasmy, heteroplasmy, maternal/cytoplasmic inheritance, clonal embryo

\section{INTRODUCTION}

Cloned mammals produced by nuclear transfer (NT) are genetic duplicates of the donor cell nuclear genome. Because, in the somatic cell nuclear transfer procedure foreign (allogeneic) mitochondria are introduced into the enucleated recipient oocyte, clonal offspring may not be genetically identical (monogenetic) to the donor cell mitochondrial genome (Evans et al., 1999; Takeda et al., 1999, 2003; Steinborn et al., 2000; St. John et al., 2004b). In other words, although cloned individuals share the same nuclear DNA, they do not have the same genomic copies of somatic mtDNA. They are not consequently the faithful replicas of their progenitory "prototype-donor" of somatic cell nuclei. Moreover, recipient oocytes are usually collected from ovaries of slaughtered females, enabling a strong selection for high-quality cytoplasts. However, such oocytes are of unknown cytoplasmic maternal origin. Therefore, if nuclear recipient ooplasts are not derived from the same maternal lineage as the donor nuclei a high level of mitochondrial genotype heterogeneity often occurs in clonal embryos and resultant offspring as a result of the variability (polymorphism) of specific mtDNA nucleotide sequences (Plante et al., 1992; Campbell, 1999a,b; Steinborn et al., 1998b; Hiendleder et al., 1999, 2004; Smith et al., 2000).

\section{EFFECT OF OOCYTE RECONSTRUCTION METHODS ON THE DISTRIBUTION OF mtDNA HETEROPLASMY IN NUCLEAR TRANSFER- DERIVED EMBRYOS}

At present, the most common embryo reconstruction techniques are nuclear transfer followed by electric pulse fusion of cytoplast (enucleated Metaphase II oocyte) with somatic cell (cattle: Cibelli et al., 1998, Wells et al., 1999, Skrzyszowska et al., 2000, Kato et al., 2000; sheep: Wilmut et al., 1997, McCreath et al., 2000; goats: Baguisi et al., 1999, Keefer et al., 2001; pigs: Koo et al., 2000, Polejaeva et al., 2000, Boquest et al., 2002, Yin et al., 2002, Skrzyszowska and 
Samiec, 2005) or the use of a suspension of inactivated Sendai virus (HVJ) particles with an accurately defined number of haemagglutination activity units (mice: Kato et al., 1999, Ono et al., 2001; horses: Li et al., 2002). Also used frequently are the procedures of microsurgical nuclear transfer, involving both direct karyoplast (cell nucleus with residual, perinuclear protoplasmic "ring" i.e. perikaryon) injection into the cytoplasm of an enucleated oocyte (pigs: Onishi et al., 2000, Lai et al., 2001, Park et al., 2001, Roh and Hwang, 2002, Samiec et al., 2003a,b, Skrzyszowska et al., 2003, Skrzyszowska and Samiec, 2004; mice: Wakayama et al., 1998, Chung et al., 2002, Kim et al., 2002; cattle: LachamKaplan et al., 2000, Do et al., 2002, Galli et al., 2002; horses: Choi et al., 2002), and whole cell intraooplasmic microinjection (pigs: Lee et al., 2003b). However, in the nuclear transfer technique by somatic cell-cytoplast couplet electrofusion or by whole cell intracytoplasmic microinjection, heteroplasmic sources of mtDNA from a donor cell and an enucleated recipient oocyte are mixed in the cytoplasm of the reconstituted embryo (Figure 1). Therefore, the oocytes reconstructed by cell fusion or microsurgical transfer of whole nuclear donor cells are allomitochondrial cybrids harbouring somatogenic mtDNA (Hiendleder et al., 1999, 2004; Steinborn et al., 2000, 2002; Meirelles et al., 2001; Gomez et al., 2003; Lee et al., 2003; St. John et al., 2004b). It is beyond any doubt that donor to recipient heteroplasmic ratios of the mitochondrial genotype in clonal embryos depend, to a high degree, on the phenotype and size of the nuclear donor cells (Takeda et al., 2003; Figure 1). For instance, in vitro cultured embryonic stem cells, fibroblast cells or cumulus and mural granulosa cells contain higher intracytosolic concentrations of mitochondria than freshly isolated cumulus cells. Similarly, cytoplasm of whole cells includes a greater mitochondria pool than a thin layer of perinuclear cytosol in the karyoplasts prepared from somatic cells before the procedure of manual or piezo-driven direct nuclear microinjection into cytoplasm of recipient oocytes (Figure 2; Steinborn et al., 1998a,b; Yamazaki et al., 1999; Wakayama and Yanagimachi, 2001; Brüggerhoff et al., 2002; Chen et al., 2002; Chung et al., 2002; Do et al., 2002; Roh and Hwang, 2002; Lee et al., 2003; Samiec et al., 2003b; Samiec, 2004; Takeda et al., 2003). Mitochondrial DNA heteroplasmy is similarly induced during the fertilization process as a result of the spermatozoon, which has a small number (approximately 50-75) of mtDNA molecules, entering the mature oocyte (Hecht et al., 1984; Smeitink et al., 2001; Schwartz and Vissing, 2002, 2003; Sutovsky, 2004). 

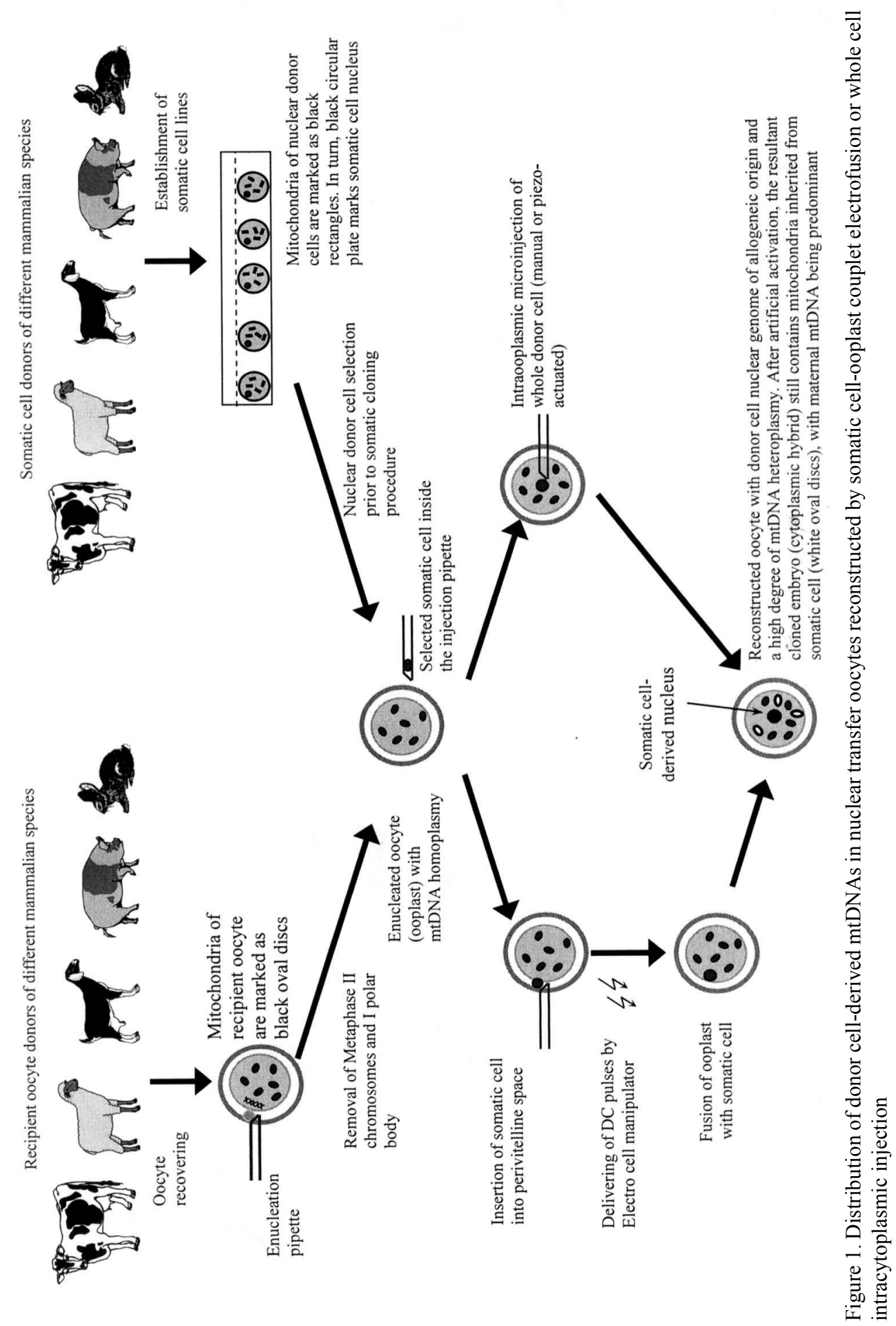

पै

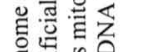

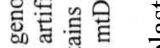

密苛

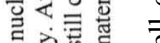

窟范

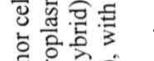

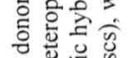




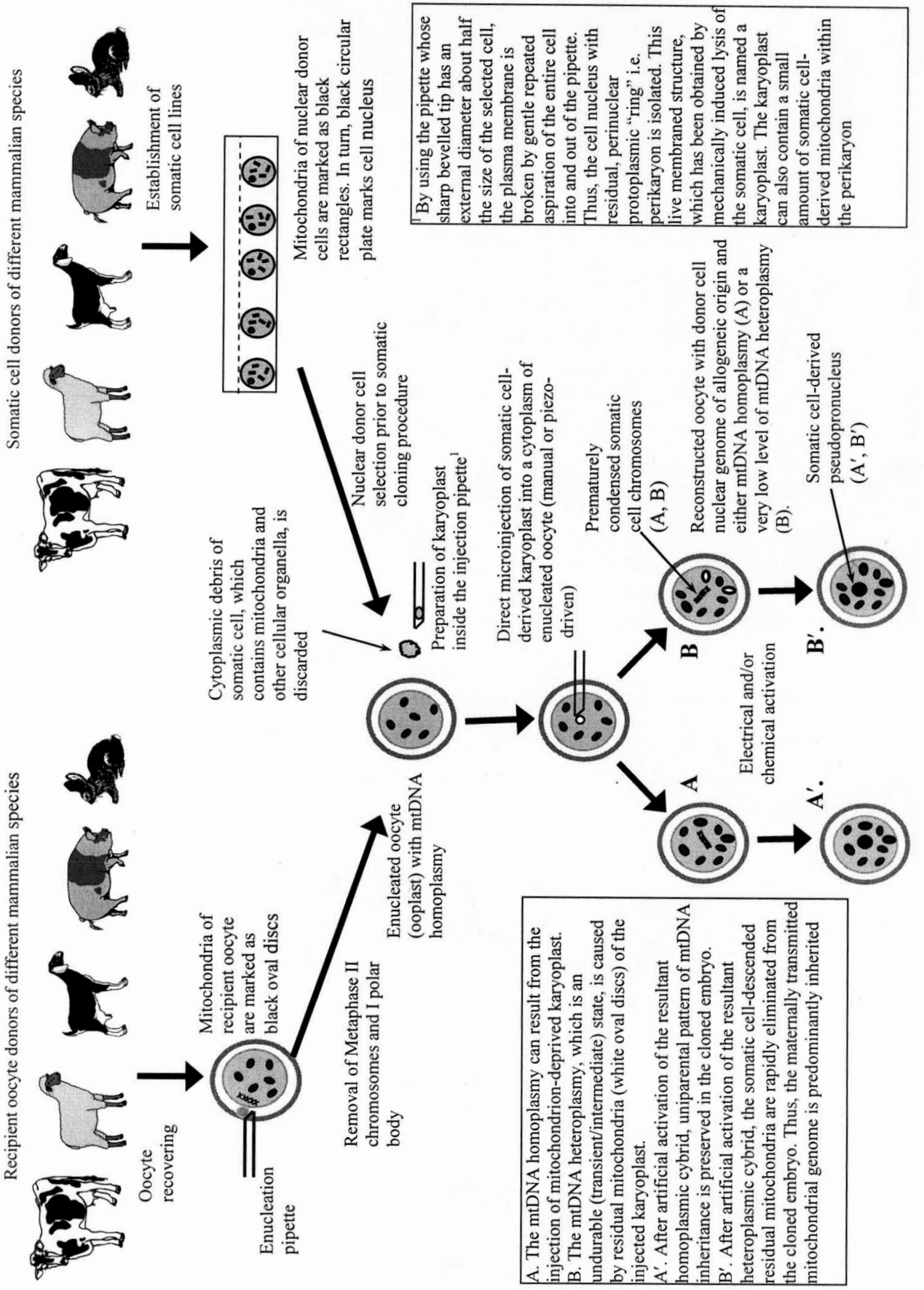

纪

छ웡 क छ 잉 휼 㐘 . 坖完 훙 证 웡 $\exists$ 즈 흘 声. ज् है 巳ัّ 论 정 这这 氖. ซै. 율

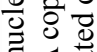
$\Xi$ Z 这表 Z 흥 흠 ठี 过 进 응. 흥 tᄒ क्षे to 도 言客 틍 Q 구요 일 壁尊 


\section{THE STRUCTURE AND FUNCTIONS OF mtDNA - NUCLEAR-MITO- CHONDRIAL INTERGENOMIC COMMUNICATION}

Quantitative and qualitative control of gene expression by nucleo-cytoplasmic interactions. Mammalian mtDNA is a double-stranded ( $\alpha$-helix) circular molecule of about 16300 to 16500 base pairs (bp), the genetics of which differs from that of the nuclear genome (Gray, 1989; Saccone and Sbisa, 1989; Lightowlers et al., 1997; Chinnery and Turnbull, 1999; Clayton, 2000; Jansen, 2000a). In the naked, histone and non-histone protein-deprived molecule of mtDNA, which is the carrier of only 37 genes, cytoplasmic (maternal) hereditary information is recorded. This information involves 13 translation products out of approximately 80 proteins taking part in the oxidative phosphorylation process (I, III, IV and V complex; II complex does not contain the polypeptides encoded in the mtDNA). It also involves about 24 transcription products, including 22 types of transporter RNA (tRNA) engaged in the biosynthesis of the above-mentioned 13 proteins on the mitochondrial ribosomes (mitoribosomes), as well as about 2 types of ribosomal RNA (rRNA) molecules $-12 \mathrm{~S}$ in the small, and $16 \mathrm{~S}$ in the large mitoribosomal subunit (Clayton, 1984; Smith et al., 2000; Trounce, 2000; Van Garesse and Vallejo, 2001; Smeitink et al., 2001; Blerkom, 2004). Nevertheless, the genetic information about the structure and types of hundreds of other proteins, present in the mitochondria, such as other residual protein components of the respiratory chain (the electron transport chain), the enzymes related to mtDNA replication, transcription and translation, the vital mtDNA transcription factors, and all ribosomal proteins is encoded in the nuclear DNA, whose singlestranded fragments are transcripted to messenger RNA (mRNA) molecules in the cell nucleus. In turn, in the cytosol, nucleotide sequences of mRNA are translated to amino acid sequences of the polypeptide chains of nuclear gene products. Only after this are the proteins synthesized outside of mitochondria translocated (imported) by way of an active (energy-dependent) transport into the intermembrane space and mitochondrial matrix (Ghivizzani et al., 1993, 1994; Clayton, 1998). They are also accumulated in the mitochondrial crests of inner mitochondrial membrane (above all inside the oxysomes/ electron transport particles including the factors coupling ATP synthesis with proton diffusion $\mathrm{F}_{0} \mathrm{~F}_{1}$, i.e. $\mathrm{H}^{+}$-transporting ATP synthetase and ATPase complexes (Capaldi, 1990; Leonard and Schapira, 2000; Trounce, 2000; Cummins, 2001b; Smeitink et al., 2001; Van Blerkom, 2004). The ultrastructural construction of mitochondria is consequently a result of close cooperation between two really independent protein biosynthesis systems, the cytoplasmic translation system encoded by the nuclear genetic apparatus and the intramitochondrial translation system (Clayton, 1998, 2000). The mitochondrial compartment provides only 13 protein products of mtDNA gene 
expression, including: 1 . cytochrome $b ; 2$. three subunits of cytochrome c oxidase (COXI, COXII, and COXIII genes) for the IV complex of the electron transport chain; 3. two subunits of ATP synthetase, constituting the V complex of electron transport chain (atp 6 and 8 genes); and 4. seven subunits of NADH dehydrogenase (ndh 1, 2, 3, 4, 4L, 5, 6 genes). All the translation products programmed in the mitochondrial genome are components of polyprotein complexes of the respiratory chain, but the polypeptides formed inside of the mitochondrial matrix represent hydrophobic parts ("tails") of these complexes, which are anchored deeply and fast in the inner mitochondrial membrane (Anderson et al., 1981; Clayton, 1984; Capaldi, 1990; Pfanner and Neupert, 1990; Smith and Alcivar, 1993; Christodoulou, 2000; Clayton, 2000; Hoekstra, 2000; Garesse and Vallejo, 2001; Chinnery, 2004).

The role of the so-called displacement loop (D-loop) or control region (CR) in the mitochondrial genome - the D-loop-related induction of mtDNA heteroplasmy. In the mtDNA structure there is an unusual concentration (close packing) of coding segments (exons). As a rule, there are no vacant places between genes. The only unique fragment, in which there are no genes - the socalled displacement loop (D-loop), is a region that contains regulatory/non-coding (intron-like) sequences responsible for initiation of replication and transcription processes of the mitochondrial genome (Clayton, 1984, 2000; Attardi, 1985). This region includes two shorter segments, known as hypervariable/hypermutable segments, which differ from individual to individual. The strands of mtDNA are named $\mathrm{H}$ (heavy-weight) and L (light-weight), respectively. In the $\mathrm{H}$ chain genetic information is recorded about sequences of 12 proteins and 14 tRNA molecules, and in the L chain, about sequences of 1 protein and 8 tRNA molecules (Anderson et al., 1981; King and Low, 1987; Gray, 1989; Saccone and Sbisa, 1989; Barritt et al., 1999; Hoekstra, 2000; Howell et al., 2000; Jansen, 2000a; Trounce, 2000; Garesse and Vallejo, 2001). Another characteristic feature of mtDNA is that gene (point) mutations are accumulated in it much more frequently than in the nuclear (genomic) DNA. This probably results from lower efficiency of the mitochondrial DNA reparation system, and also from greater frequency of semiconservative autoreplication of mutated mtDNA molecules (shorter molecules of mtDNA, formed as a result of large nucleotide deletions are duplicated more quickly than molecules of correct size). An additional factor favouring the induction of mutation (mutagenesis) can be the influence of free radicals (ROS; reactive oxygen species) arising in the oxidative phosphorylation process. The result of many mutations is, among others, high variability/mutability of sequences observed in the control region (CR) also known as the D-loop (Attardi, 1985; Capaldi, 1990; Chinnery and Turnbull, 1999; Leonard and Schapira, 2000; Smeitink et al., 2001; Chinnery, 2004). This segment of about $1274 \mathrm{bp}$ is found between genes of proline tRNA and phenylalanine tRNA and contains operon for $\mathrm{H}$ strand replication $\left(\mathrm{O}_{\mathrm{H}}\right)$ and 
transcription promotors of $\mathrm{H}$ chain (purine-rich) and $\mathrm{L}$ strand (pyrimidine-rich); (Clayton, 1984, 1998, 2000; Attardi, 1985; Ghivizzani et al., 1993, 1994; Cummins, 2001a, 2002). In spite of many important functions the D-loop in mtDNA still has a striking pattern of nucleotide substitution and is useful for evolutionary investigations of genetic variations (identification of the mtDNA polymorphism; Greenberg et al., 1983; Gray, 1989; Hoekstra, 2000; Jansen, 2000a). Moreover, it is worth adding that the lower stream, of heavy-strand replication origin, is the most variable region in the D-loop (Saccone and Sbisa, 1989; Horai and Hayasaka, 1990; Barritt et al., 1999; Clayton, 2000; Howell et al., 2000; Trounce, 2000; Brenner, 2004). For that reason, it is widely used for studying the mtDNA heteroplasmy phenomenon.In summary, the cellular mtDNA heteroplasmy derived from spontaneous mutations (including deletions, insertions and duplications) of mtDNA is a consequence of polymorphic variation of regulatory sequences in heterogeneous displacement loop variants (Takeda et al., 1997; Christodoulou, 2000; Clayton 2000; St. John et al., 2004a; Sutovsky, 2004). The rule, in nuclear DNA polymorphism studies, is the homogeneity of its sequences in all of the somatic cells of one organism. By contrast, in the case of mtDNA the heteroplasmy occurs. Therefore, both correct and mutated (gene mutation-affected) mtDNA molecules can be present inside a single mitochondrion, and also between different mitochondria of the same cell (Capaldi, 1990; Barritt et al., 1999; Chinnery and Turnbull, 1999; Jansen, 2000b; Garesse and Vallejo, 2001; Schwartz and Vissing, 2003). Although heteroplasmic transmission of mtDNAs leads to accumulating the multiple rearranged copies of the extranuclearly inherited genome (the so-called polymorphic mitotypes) in individual mitochondria of somatic cells, only a single mtDNA copy is found in those of the meiotic Prophase I dictyotene-arrested oocyte derived from primordial ovarian follicle (Lightowlers et al., 1997; Jansen and de Boer, 1998). The dictyotene oocytes from primordial follicles contain approximately 10 mitochondria. In turn, the mtDNA molecules within them are clonally amplified from early oogenesis and acquirement of meiotic competence by oocytes released from meiotic block at germinal vesicle $(\mathrm{GV})$ stage up until complete cytoplasmic, nuclear and epigenomic maturation at metaphase II stage of meiosis (Smith and Alcivar, 1993; Marchington et al., 1997; Jansen and de Boer, 1998). This autoreplicative expansion/proliferation results in more than $10^{5}$ copies being present in those oocytes deemed capable of fertilization and maintaining embryonic development (Cummins, 1998; Reynier et al., 2001). It appears that mtDNA heteroplasmy is unstable and rapidly tends to become cellular homoplasmic condition by random cytoplasmic distribution of extranuclear genetic material during early oogenesis (the so-called "bottleneck" effect). This genetic "bottleneck" event in the meiotic dictyotene-arrested oocytes is postulated to occur in a limited number of homogeneous (mutation-free) mtDNA copies (the restriction to a few 
genome fractions deprived of mtDNA rearrangements) that are selected for clonal expansion (induction of replicative activity) during oocyte development (Jenuth et al., 1996; Smith et al., 2002). This "bottleneck" mtDNA selection is thought to be proceeded by random genetic drift and/or non-directed segregation promoting the homoplasmic transmission of mitochondrial genome (Hauswirth and Laipis, 1982; Poulton, 1995). Therefore, high degree of mtDNA heteroplasmy distribution shifts quickly to a decrease in the frequency of extranuclear genomic rearrangements during oocyte growth and after germinal vesicle breakdown (GVBD). If a limited number of mtDNA contains rearrangements (gene mutations) in single oocytes, there would most likely be no adverse effect on the amount of ATP being produced. The presence of any rearranged mtDNA copies may not be meaningful, especially if one assumes that mutated mitochondrial genome is not replicated. In fact, this may be a possible mechanism for selective elimination of the damaged mitochondria from the ooplasm. However, if a larger copy number of mtDNA contains structural and functional rearrangements there may be detrimental effects on ATP synthesis, and a higher probability of mutated extranuclear genetic material being selected for autoreplication during clonal proliferation (Poulton, 1995; Jenuth et al., 1996; Reynier et al., 2001; Smith et al., 2002).

\section{THE CAUSES OF mtDNA HETEROPLASMY INDUCTION IN SOMATIC AND EMBRYO CELL NUCLEAR TRANSFER}

Nuclear transfer embryos produced by standard cell electrofusion have a high level of mitochondrial heteroplasmy (Figure 1), because they are cytoplasmic hybrids (somato-gametogenic cybrids), from the biological (cytological) point of view (Steinborn et al., 1998a,b, 2002; Evans et al., 1999; Do et al., 2001, 2002; Hiendleder et al., 2003, 2004; St. John et al., 2004a,b). "Mitochondrial deposits" of cytobiochemical energy and extranuclear (cytoplasmic) genetic apparatus can occupy in up to $12 \%$ of the cytosol volume of somatic donor cells. Most somatic cells contain approximately $10^{3}$ mitochondria (Giles et al., 1980; Barritt et al., 1999). The actual amount depends on such factors as their cell's metabolic activity and intracellular spatial organization (configuration) of cytoskeleton and membrane skeleton microfilament network; also their ultrastructuro-functional specialization within the framework of both cytodifferentiation and exactly defined tissue- and organ-related histological topography and tissue-specific nuclear DNA and mtDNA gene expression (transcriptional activity) patterns (Moyes et al., 1998; Garesse and Vallejo, 2001; Gahan et al., 2001; Smeitink et al., 2001; Miller et al., 2003; Takeda et al., 2003). In most types of somatic cells that are the source of nuclear donors in the cloning procedure, the number of mtDNA molecules ranges 
from about $2 \times 10^{3}$ to about $5 \times 10^{3}$ copies, i.e. a proportion of 1-10 molecules per one mitochondrion (Giles et al., 1980; Michaels et al., 1982; King and Attardi, 1989; Evans et al., 1999). On the whole all the mtDNA copies are exactly genetically identical (cellular homoplasmy). In contrast, the number of mtDNA molecules in a single mature recipient oocyte arrested at metaphase II stage, which has the largest amount of mitochondria in the cytoplasm, is about $1.6 \times 10^{5}$ in mice (Hauswirth and Laipis, 1985; Steuerwald et al., 2000), $2.5 \times 10^{5}$ in cattle (Michaels et al., 1982; Hauswirth and Laipis, 1985) and 3-8 $\times 10^{5}$ in humans (Hauswirth and Laipis, 1985; Barritt et al., 2002). That is why, in the hybridic cytoplasmic microenvironment of reconstructed embryo, the mitochondrial heteroplasmy reaches the critical level of heterogenous sequence variants of DNA. Such changes may be neutral, and may not cause developmental embryonal and foetal anomalies. However, they can also evoke functional disturbances of the mitochondria, and thereby lethal anatomical and histopathological defects in the foetal and extrafoetal (placental) tissues, resulting from intracellular respiration faults (Capaldi, 1990; Pfanner and Neupert, 1990; Cummins, 1998; Jansen, 2000b; Leonard and Schapira, 2000, 2001a,b; Steinborn et al., 2000, 2002; Brüggerhoff et al., 2002; Brenner, 2004; St. John et al., 2004b; Van Blerkom, 2004). The frequency of heteroplasmic mutagenesis, measured with polymorphic variation of mtDNA sequences undoubtedly depends on abnormalities in the reprogramming process of the epigenetic modifications of the nuclear and mitochondrial genome. These epimutations can lead to excessive gene silencing or gene expression (transcription), in particular in those mtDNA segments which encode information about protein components of the electron transport chain, e.g., in ND1 to ND3 (NADH dehydrogenase) genes or in COXII (cytochrome c oxidase) gene (Lightowlers et al., 1997; Shitara et al., 1998; Trounce, 2000; Cummins, 2001a; Rideout III et al., 2001; Surani, 2001; Hiendleder et al., 2004; St. John et al., 2004a).

\section{SEGREGATION PATTERNS OF NUCLEAR DONOR AND RECIPIENT OOCYTE MITOCHONDRIAL GENOTYPES (MITOTYPES) IN CLONED EMBRYOS}

Conservation of uniparental (maternal) inheritance of the mitochondrial genome or aberrant (heteroplasmic) mtDNA transmission (i.e. biparental inheritance) in nuclear-transferred embryos. The distribution of mtDNA heteroplasmy in NT bovine embryos and resultant offspring was investigated by measuring the polymorphism in the displacement loop region of mtDNA using polymerase chain reaction-mediated single-strand conformation polymorphism analysis (PCR-SSCP; Takeda et al., 1999). Most offspring (20 of 21 cloned 
calves) derived from embryos reconstituted with recipient oocytes of undefined mitochondrial DNA genotypes showed different genotypes (haplotypes) from the mtDNA of donor cells. One calf that was an exception showed heteroplasmy, including the donor mtDNA genotype. Six cloned calves were produced from oocytes of a defined mtDNA genotype (haplotype). All of these clonal members and various tissues showed only the mtDNA genotype originating from the enucleated oocyte (cytoplast). The most likely explanation of this phenomenon is that the mtDNA from donor cells was eliminated during early embryonic development. The mtDNA genotypes of the NT embryos recovered immediately after blastomere-cytoplast fusion were heteroplasmic, consistent with the view that mtDNAs from both donor cells and recipient oocytes were present. However, the level of donor mitochondrial genome gradually decreased at the four- to eight-cell cleavage stages and was hardly detectable by the blastocyst stage. During bovine embryonic development, mitochondria, which are semiautonomous organelles capable of independent interphase duplication (biogenesis) in consequence of their own DNA autoreplication at G2 stage of cell cycle (in contradistinction to nuclear DNA undergoing replication at S phase of division cycle), show extensive morphological transformation associated with intensive nucleologenesis and/or nucleolar architecture reconstruction (Plante and King, 1994). These results are contrary to the studies on the fate of mtDNA throughout preimplantation development of mouse embryos (Piko and Taylor, 1987). It has been confirmed that there is no mtDNA semiconservative replication until the blastocyst (approx. 100-cell) stage of murine embryogenesis. Thus, each of the 20 cells of the inner cell mass (ICM) that ultimately develop into the foetal body contains about 1000 copies of mtDNA, which are probably inherited from the oocyte cytoplasmic environment. Analysis of the initiation of mtDNA transcription and autoreplication during preimplantation development of mouse embryos revealed that both these processes are regulated by nuclear genome-encoded transcription factors that are imported into the mitochondria of embryonic cells (Clayton, 2000). Transcription proceeds from the 2-blastomere stage in the developing mouse embryos although the number of mitochondrial genome copies is constant until the blastocyst stage (Piko and Taylor, 1987; Cummins, 2002; Brenner, 2004). The proportion of mitochondrial genome (measured with the mtDNA copy number per both each mitochondrion and each blastomere) is probably maintained by nuclear respiratory factor (NRF)-1, whose synthesis is dependent on the metabolic activity of whole murine embryo (Clayton, 1998; Huo and Scarpulla, 2001). It has been shown that the homozygous mouse embryos with targeted disruption of NRF-1 gene exhibit a decrease of pre- and/or peri-implantation survival rate (high lethality degree) and are able to develop to day 6.5 of embryogenesis (Huo and Scarpulla, 2001). Moreover, there is continual dilution of the mitochondrial genome fractions, 
which are transmitted to each new cleavage division-descended blastomere, until the mtDNA replicative activity is induced post implantation. One of the most important regulators of the mtDNA autoreplication is mitochondrial transcription factor A (mtTFA) that has a strong affinity for the conserved sequence block (CSB)-1 of the D-loop and by binding to the control region is involved in the initiation of heavy-strand DNA synthesis (Ghivizzani et al., 1993, 1994; Larsson et al., 1994; Clayton, 2000). It has been also demonstrated that the mitochondrial genome of homozygous murine embryos with one allele knock-out of the mtTFA gene has severe DNA depletion. That is why the survival rate of these transgenic embryos persists no longer than to day 10.5 of development. This is in contrast with heterozygous genetically engineered offspring that phenotypically exhibit symptoms of cardiomyopathy, a severe debilitating disorder of the mtDNA (Larsson et al., 1998).

However, in bovine embryos, mitochondrial ultrastructuro-functional maturation, involving among others the resumption of transcriptional activity of mtDNA genes, begins at the eight-blastomere stage and is complete by the blastocyst stage. King et al. (1996) reported that, in bovine cloned embryos, mature mitochondria that were probably carried along with the donor cells were observed at the one- to four-cell stages. That is why it is speculated that mature autoreplicating mitochondria, transferred with nuclear donor embryonic or somatic cells into recipient ooplasts, may be broken down in the blastomere cytoplasm of reconstituted embryos during the above mentioned morphological transformation and genomic maturation of mitochondria during preimplantation embryogenesis (Takeda et al., 1999; Do et al., 2001; Meirelles et al., 2001).

Molecular mechanisms of cytoplasmic (mitochondrial) inheritance in embryos derived from nuclear-transferred and fertilized oocytes - similarities and/or differences. Results of the examinations by Takeda and co-workers (1999) indicate that the genotype (haplotype) of mtDNA from recipient oocytes (originating from maternal inheritance and probably also undergoing the epigenetic mechanisms of parental genome imprinting analogous to the ones taking place in nuclear genetic apparatus) may become the dominant category of mtDNA in calves derived by nuclear transfer performed using the electrofusion technique. This spontaneous process of removal (intracellular degradation) of the mitochondrial genome of exogenous origin (from nuclear donor cells) in the hybridic cytoplasmic microenvironment of blastomeres, (known as the nulling/zeroing of the DNA heterogeneity phenomenon inside the intracellular mitochondria population), can be a defensive (immunological) reaction of clonal embryos against the heteroplasmic mutagenesis of mtDNA. It thus prevents resultant negative effects of improper epigenetic reprogramming of donor nuclear and mitochondrial DNA. It also avoids disturbances in the preservation of the correct genetic apparatus 
methylation pattern in the parental (paternal or maternal) genome imprints (Kikyo and Wolffe, 2000; Renard et al., 2002; Mann et al., 2003; Cummins, 2004; Hiendleder et al., 2004; St. John et al., 2004a,b; Sutovsky, 2004). Thus, it is similar to the scenario of molecular events occurring in the activated oocyte following in vivo or in vitro monospermic fertilization. Before the zygote has reached the late pronuclear stage (in intraspecific crossings of mice) or after the zygote has cleaved several times (in livestock species), mtDNA heteroplasmy is erased by the mechanism of sequential destruction and exclusion of the sperm mtDNA from the cytoplasm of embryonic cells (Kaneda et al., 1995; Sutovsky et al., 1996; Shitara et al., 2001; Schwartz and Vissing, 2002, 2003). The mtDNA therefore shows inheritance by predominantly maternal cytoplasmic exchange (Gyllensten et al., 1985; Cummins, 1998; Brenner, 2004). In other words, the mitochondrial genome is inherited homoplasmically through selective elimination (segregation) of mtDNA molecules of paternal origin (from spermatozoon midpiece) by the late pronuclear stage in murine embryos (Kaneda et al., 1995; Shitara et al., 1998), and before the 8-blastomere stage in bovine nad rhesus macaque embryos (Sutovsky et al., 1999, 2000; Johns, 2003). For that reason, only the oocyte-derived mitochondria are assumed to be transmitted to the offspring (Shitara et al., 2001; Schwartz and Vissing, 2002). This species-specific mechanism of sperm (and probably somatic or embryonic donor cell) mitochondria "ousting", resulting in intracellular prevention, neutralization, or inhibition of the paternal mtDNA "leakage" phenomenon in dividing fertilized ova (zygotes) or nuclear-transferred embryos, is presumably caused by a ubiquitin-tagging system and subsequent proteasomal or lysosomal degradation of these ubiquitinated (previously ubiquitin-tagged) organelles (Sutovsky et al., 1999, 2000; Do et al., 2001, 2002; Chen et al., 2002; Hiendleder et al., 2003; Schwartz and Vissing, 2003; Sutovsky, 2004).

\section{THE PROBLEM OF “IDEAL” MAMMALIAN CLONE CREATION}

In conclusion, it is worth noting that when cloning both embryos and adult individuals, what is often forgotten is the presence in the cytoplasm of donor- and recipient-cells of mtDNA, which is certain to contain small (approximately $0.01 \%$ ) amounts of total cell genetic information, but it is different from information recorded in the nuclear DNA (99.99\% of the cellular genome; Smith and Alcivar, 1993; Meirelles and Smith, 1998; Evans et al., 1999; Takeda et al., 1999; Howell et al., 2000; Jansen, 2000a). If the relative largeness of the mitochondrial genome, enclosed in the circular DNA molecule, is measured with the quantitative ratio/ proportion of base pairs of nucleotide sequences in genomic double-stranded DNA $\alpha$-helix, it is approximately $0.0005 \%$ of the nuclear genome (Lightowlers et 
al., 1997; Garesse and Vallejo, 2001). In this respect, introduction of a donor cell nucleus into the oocyte derived from another individual leads to the generation of hybridic (in terms of genetic mitochondrial apparatus) reconstructed oocytes, which evidently can have a certain influence on the genotype and phenotype identity of the offspring produced by cloning. The "ideal" clone can be obtained only with donor cell nucleus transplanted into the oocyte originating from the same individual; therefore the "ideal mammalian clones" can be only the clones of females whose overall mitochondrial genome should have a completely homogenous pattern of regulatory (intron-like or pseudogene) and coding (exon) nucleotide sequences of all the cellular mtDNA copies in all the somatic and germ cell lines (Steinborn et al., 2000; Brüggerhoff et al., 2002; Takeda et al., 2003). The characteristic feature of such clone populations is the occurrence of both intracellular and intercellular variants of mitochondrial homoplasmy among all of their own tissues. An exception is the so-called "mtDNA heteroplasmy hot places", e.g., in hair epidermal cells, which are very susceptible to spontaneous point mutations (as a result of high frequency of purine and pyrimidine base substitution), particularly, in the control segment of the displacement loop (Do et al., 2001, 2002; Meirelles et al., 2001; Hiendleder et al., 2003, 2004).

\section{REFERENCES}

Anderson S., Bankier A.T., Barrell B.G., de Bruijn M.H., Coulson A.R., Drouin J., Eperon I.C., Nierlich D.P., Roe B.A., Sanger F., Schreier P.H., Smith A.J., Staden R., Young I.G., 1981. Sequence and organization of the human mitochondrial genome. Nature 290, 457-465

Attardi G., 1985. Animal mitochondrial DNA: an extreme example of genetic economy. Int. Rev. Cytol. 93, 93-145

Baguisi A., Behboodi E., Melican D.T., Pollock J.S., Destrempes M.M., Cammuso C., Williams J.L., Nims S.D., Porter C.A., Midura P., Palacios M.J., Ayres S.L., Denniston R.S., Hayes M.L., Ziomek C.A., Meade H.M., Godke R.A., Gavin W.G., Overstrom E.W., Echelard Y., 1999. Production of goats by somatic cell nuclear transfer. Nat. Biotechnol. 17, 456-461

Barritt J.A., Brenner C.A., Cohen J., Matt D.W., 1999. Mitochondrial DNA rearrangements in human oocytes and embryos. Mol. Hum. Reprod. 5, 927-933

Barritt J.A., Kokot M., Cohen J., Steuerwald N., Brenner C.A., 2002. Quantification of human ooplasmic mitochondria. Reprod. BioMed. Online 4, 243-247

Boquest A.C., Grupen C.G., Harrison S.J., McIlfatrick S.M., Ashman R.J., d'Apice A.J.F., Nottle M.B., 2002. Production of cloned pigs from cultured fetal fibroblast cells. Biol. Reprod. 66, 1283-1287

Brenner C., 2004. What is the role of mitochondria in embryo competence? In: J. Van Blerkom, L. Gregory (Editors). Essential IVF: Basic Research and Clinical Applications. Kluwer Academic Publishers, Boston, pp. 273-290

Brüggerhoff K., Zakhartchenko V., Wenigerkind H., Reichenbach H.-D., Prelle K., Scernthaner W., Alberio R., Kuchenhoff H., Stojkovic M., Brem G., Hiendleder S., Wolf E., 2002. Bovine 
somatic cell nuclear transfer using recipient oocytes recovered by ovum pick-up: effect of maternal lineage of oocyte donors. Biol. Reprod. 66, 367-373

Campbell K.H.S., 1999a. Nuclear transfer in farm animal species. Cell Dev. Biol. 10, 245-252

Campbell K.H.S., 1999b. Nuclear equivalence, nuclear transfer, and the cell cycle. Cloning 1, 3-15 Capaldi R.A., 1990. Structure and function of cytochrome c oxidase. Ann. Rev. Biochem. 59, 569-596

Chen D.-Y., Wen D.-C., Zhang Y.-P., Sun Q.-Y., Han Z.-M., Liu Z.-H., Shi P., Li J.-S., Xiangyu J.-G., Lian L., Kou Z.-H., Wu Y.-Q., Chen Y.-C., Wang P.-Y., Zhang H.-M., 2002. Interspecies implantation and mitochondria fate of panda-rabbit cloned embryos. Biol. Reprod. 67, 637-642

Chinnery P., 2004. New approaches to the treatment of mitochondrial disorders. Reprod. BioMed. Online 8, 16-23

Chinnery P., Turnbull D., 1999. Mitochondrial DNA and disease. Lancet 354, Suppl., S117-S121

Choi Y.H., Love C.C., Chung Y.G., Varner D.D., Westhusin M.E., Burghardt R.C., Hinrichs K., 2002. Production of nuclear transfer horse embryos by piezo-driven injection of somatic cell nuclei and activation with stallion sperm cytosolic extract. Biol. Reprod. 67, 561-567

Christodoulou J., 2000. Genetic defects causing human mitochondrial respiratory chain disorders and disease. Hum. Reprod. 15, Suppl. 2, 28-43

Chung Y.G., Mann M.R.W., Bartolomei M.S., Latham K.E., 2002. Nuclear-cytoplasmic "tug of war" during cloning: effects of somatic cell nuclei on culture medium preferences of preimplantation cloned mouse embryos. Biol. Reprod. 66, 1178-1184

Cibelli J.B., Stice S.L., Goluece P.J., Kane J.J., Jerry J., Blackwell C., Ponce de Leon F.A., Robl J.M., 1998. Cloned transgenic calves produced from nonquiescent fetal fibroblasts. Science 280, 1256-1258

Clayton D.A., 1984. Transcription of mammalian mitochondrial genome. Ann. Rev. Biochem. 53, 573-594

Clayton D.A., 1998. Nuclear-mitochondrial intergenomic communication. Biofactors 7, 203-205

Clayton D.A., 2000. Transcription and replication of mitochondrial DNA. Hum. Reprod. 15, Suppl. 2,11-17

Cummins J.M., 1998. Mitochondrial DNA in mammalian reproduction. Rev. Reprod. 3, 172-182

Cummins J.M., 2001a. Mitochondria: potential roles in embryogenesis and nucleocytoplasmic transfer. Hum. Reprod. 7, 217-228

Cummins J.M., 2001b. Cytoplasmic inheritance and its implications for animal biotechnology. Theriogenology 55, 1381-1399

Cummins J.M., 2002. The role of maternal mitochondria during oogenesis, fertilization and embryogenesis. Reprod. BioMed. Online 4, 176-182

Do J.T., Hong K.H., Lee B.Y., Kim S.B., Kim N.H., Lee H.T., Chung K.S., 2001. In vitro development of reconstructed bovine embryos and fate of donor mitochondria following nuclear injection of cumulus cells. Zygote 9, 211-218

Do J.T., Lee J.W., Lee B.Y., Kim S.B., Ryoo Z.Y., Lee H.T., Chung K.S., 2002. Fate of donor mitochondrial DNA in cloned bovine embryos produced by microinjection of cumulus cells. Biol. Reprod. 67, 555-560

Evans M.J., Gurer C., Loike J.D., Wilmut I., Schnieke A.E., Schon E.A., 1999. Mitochondrial DNA genotypes in nuclear transfer-derived cloned sheep. Nat. Genet. 23, 90-93

Gahan M.E., Miller F., Lewin S.R., Cherry C.L., Hoy J.F., Mijch A., Rosenfeldt F., Wesselingh S.L., 2001. Quantification of mitochondrial DNA in peripheral blood mononuclear cells and subcutaneous fat using real-time polymerase chain reaction. J. Clin. Virol. 22, 241-247

Galli C., Lagutina I., Vassiliev I., Duchi R., Lazzari G., 2002. Comparison of microinjection (piezoelectric) and cell fusion for nuclear transfer success with different cell types in cattle. Cloning Stem Cells 4 (3), 189-196

Garesse R., Vallejo C.G., 2001. Animal mitochondrial biogenesis and function: a regulatory crosstalk between two genomes. Gene 263, 1-16 
Ghivizzani S.C., Madsen C.S., Hauswirth W.W., 1993. In organello footprinting. Analysis of protein binding at regulatory regions in bovine mitochondrial DNA. J. Biol. Chem. 268, 8675-8682

Ghivizzani S.C., Madsen C.S., Nelen M.R., Ammini C.V., Hauswirth W.W., 1994. In organello footprint analysis of human mitochondrial DNA: human mitochondrial transcription factor A interactions at the origin of replication. Mol. Cell. Biol. 14, 7717-7730

Giles R.E., Blanc H., Cann H.M., Wallace D.C., 1980. Maternal inheritance of human mitochondrial DNA. Proc. Natl. Acad. Sci. USA 77, 6715-6719

Gomez M.C., Jenkins J.A., Giraldo A., Harris R.F., King A., Dresser B.L., Earle Pope C., 2003. Nuclear transfer of synchronized African wild cat somatic cells into enucleated domestic cat oocytes. Biol. Reprod. 69, 1032-1041

Gray M.W., 1989. Origin and evolution of mitochondrial DNA. Ann. Rev. Cell Biol. 5, 25-50

Greenberg B.D., Newbold J.E., Sugino A., 1983. Intraspecific nucleotide sequence variability surrounding the origin of replication in human mitochondrial DNA. Gene 21, 33-49

Gyllensten U., Wharton D., Wilson A.C., 1985. Maternal inheritance of mitochondrial DNA during backcrossing of two species of mice. J. Hered. 76, 321-324

Hauswirth W.W., Laipis P.J., 1982. Mitochondrial DNA polymorphism in a maternal lineage of Holstein cows. Proc. Natl. Acad. Sci. USA 79, 4686-4690

Hauswirth W.W., Laipis P.J., 1985. Transmission genetics of mammalian mitochondria: a molecular model and experimental evidence. In: E. Quagliariello, E.C. Slater, F. Palmieri, C. Saccone, A.M. Kroon (Editors). Achievements and Perspectives of Mitochondrial Research Vol. II: Biogenesis. Elsevier Science Publishers, Amsterdam, pp. 49-59

Hecht N.B., Liem H., Kleene K.C., Distel R.J., Ho S.M., 1984. Maternal inheritance of the mouse mitochondrial genome is not mediated by a loss or gross alteration of the paternal mitochondrial DNA or by methylation of the oocyte mitochondrial DNA. Develop. Biol. 102, 452-461

Hiendleder S., Prelle K., Brüggerhoff K., Reichenbach H.-D., Wenigerkind H., Bebbere D., Stojkovic M., Müller S., Brem G., Zakhartchenko V., Wolf E., 2004. Nuclear-cytoplasmic interactions affect in utero developmental capacity, phenotype, and cellular metabolism of bovine nuclear transfer fetuses. Biol. Reprod. 70, 1196-1205

Hiendleder S., Schmutz S.M., Erhardt G., Green R.D., Plante Y., 1999. Transmitochondrial differences and varying levels of heteroplasmy in nuclear transfer cloned cattle. Mol. Reprod. Dev. 54, 24-31

Hiendleder S., Zakhartchenko V., Wenigerkind H., Reichenbach H.-D., Brüggerhoff K., Prelle K., Brem G., Stojkovic M., Wolf E., 2003. Heteroplasmy in bovine fetuses produced by intra- and inter-subspecific somatic cell nuclear transfer: neutral segregation of nuclear donor mitochondrial DNA in various tissues and evidence for recipient cow mitochondria in fetal blood. Biol. Reprod. 68, 159-166

Hoekstra R., 2000. Evolutionary origin and consequences of uniparental mitochondrial inheritance. Hum. Reprod. 15, Suppl. 2, 102-111

Horai S., Hayasaka K., 1990. Intraspecific nucleotide sequence differences in the major noncoding region of human mitochondrial DNA. Amer. J. Hum. Genet. 46, 828-842

Howell N., Chinnery P., Ghosh S.S., Fahy E., Turnbull D.M., 2000. Transmission of the human mitochondrial genome. Hum. Reprod. 15, Suppl. 2, 235-245

Huo L., Scarpulla L.C., 2001. Mitochondrial DNA instability and peri-implantation lethality associated with targeted disruption of nuclear respiratory factor 1 in mice. Mol. Cell Biol. 21, 644-654

Jansen R., 2000a. Origin and persistence of the mitochondrial genome. Hum. Reprod. 15, Suppl. 2, 1-10

Jansen R., 2000b. Germline passage of mitochondria: quantitative considerations and possible embryological sequelae. Hum. Reprod. 15, Suppl. 2, 112-128

Jansen R.P., de Boer K., 1998. The bottleneck: mitochondrial imperatives in oogenesis and ovarian follicular state. Mol. Cell. Endocrinol. 145, 81-88 
Jenuth J.P., Peterson A.C., Fu K., Shoubridge E.A., 1996. Random genetic drift in the female germline explains the rapid segregation of mammalian mitochondrial DNA. Nat. Genet. 14, 146-151

Johns D., 2003. Paternal transmission of mitochondrial DNA is (fortunately) rare. Ann. Neurol. 54, $422-424$

Kaneda H., Hayashi J., Takahama S., Taya C., Lindahl K.F., Yonekawa H., 1995. Elimination of paternal mitochondrial DNA in intraspecific crosses during early mouse embryogenesis. Proc. Natl. Acad. Sci. USA 92, 4542-4546

Kato Y., Tani T., Tsunoda Y., 2000. Cloning of calves from various somatic cell types of male and female adult, newborn and fetal cows. J. Reprod. Fertil. 120, 231-237

Kato Y., Yabuuchi A., Motosugi N., Kato J., Tsunoda Y., 1999. Developmental potential of mouse follicular epithelial cells and cumulus cells after nuclear transfer. Biol. Reprod. 61, 1110-1114

Keefer C.L., Baldassarre H., Keyston R., Wang B., Bhatia B., Bilodeau A.S., Zhou J.F., Leduc M., Downey B.R., Lazaris A., Karatzas C.N., 2001. Generation of dwarf goat (Capra hircus) clones following nuclear transfer with transfected and nontransfected fetal fibroblasts and in vitro matured oocytes. Biol. Reprod. 64, 849-856

Kikyo N., Wolffe A.P., 2000. Reprogramming nuclei: insights from cloning, nuclear transfer and heterokaryons. J. Cell Sci. 113, 11-20

Kim J.-M., Ogura A., Nagata M., Aoki F., 2002. Analysis of the mechanism for chromatin remodeling in embryos reconstructed by somatic nuclear transfer. Biol. Reprod. 67, 760-766

King M.P., Attardi G., 1989. Human cells lacking mtDNA: repopulation with exogenous mitochondria by complementation. Science $246,500-503$

King T.C., Low R.L., 1987. Mapping of control elements in the displacement loop region of bovine mitochondrial DNA. J. Biol. Chem. 262, 6204-6213

King W.A., Shepherd D.L., Plante L., Lavoir M.C., Looney C.R., Barnes F.L., 1996. Nucleolar and mitochondrial morphology in bovine embryos reconstructed by nuclear transfer. Mol. Reprod. Dev. 44, 499-506

Koo D.-B., Kang Y.-K., Choi Y.-H., Park J.S., Han S.-K., Park I.Y., Kim S.-U., Lee K.-K., Son D.S., Chang W.-K., Han Y.-M., 2000. In vitro development of reconstructed porcine oocytes after somatic cell nuclear transfer. Biol. Reprod. 63, 986-992

Lacham-Kaplan O., Diamente M., Pushett D., Lewis I., Trounson A., 2000. Developmental competence of nuclear transfer cow oocytes after direct injection of fetal fibroblast nuclei. Cloning 2, 55-62

Lai L., Tao T., Machaty Z., Kühholzer B., Sun Q.-Y., Park K.-W., Day B.N., Prather R.S., 2001. Feasibility of producing porcine nuclear transfer embryos by using G2/M-stage fetal fibroblasts as donors. Biol. Reprod. 65, 1558-1564

Larsson N.G., Oldfors A., Holme E., Clayton D.A., 1994. Low levels of mitochondrial transcription factor A in mitochondrial DNA depletion. Biochem. Biophys. Res. Commun. 200, 1374-1381

Larsson N.G., Wang J., Wilhelmsson H., Oldfors A., Rustin P., Lewandoski M., Barsh G.S., Clayton D.A., 1998. Mitochondrial transcription factor A is necessary for mtDNA maintenance and embryogenesis in mice. Nat. Genet. 18, 231-236

Lee J.-W., Wu S.-C., Tian X.C., Barber M., Hoagland T., Riesen J., Lee K.-H., Tu C.-F., Cheng W.T.K., Yang X., 2003. Production of cloned pigs by whole-cell intracytoplasmic microinjection. Biol. Reprod. 69, 995-1001

Leonard J., Shapira A., 2000. Mitochondrial respiratory chain disorders. I Mitochondrial DNA defects. Lancet 355, 299-304

Li X., Morris H.-A., Allen W.R., 2002. In vitro development of horse oocytes reconstructed with the nuclei of fetal and adult cells. Biol. Reprod. 66, 1288-1292

Lightowlers R.N., Chinnery P.F., Turnbull D.M., Howell N., 1997. Mammalian mitochondrial genetics: heredity, heteroplasmy and disease. Trends Genet. 13, 450-455 
Mann M.R.W., Chung Y.G., Nolen L.D., Verona R.I., Latham K.E., Bartolomei M.S., 2003. Disruption of imprinted gene methylation and expression in cloned preimplantation stage mouse embryos. Biol. Reprod. 69, 902-914

Marchington D.R., Hartshorne G.M., Barlow D., Poulton J., 1997. Homopolymeric tract heteroplasmy in mtDNA from tissues and single oocytes: support for a genetic bottleneck. Amer. J. Hum. Genet. 60, 408-416

McCreath K.J., Howcroft J., Campbell K.H.S., Colman A., Schnieke A.E., Kind A.J., 2000. Production of gene targeted sheep by nuclear transfer from cultured somatic cells. Nature 405, 1066-1069

Meirelles F.V., Smith L.C., 1998. Mitochondrial genotype segregation during preimplantation development in mouse heteroplasmic embryos. Genetics 148, 877-883

Meirelles F.V., Bordignon V., Watanabe Y., Watanabe M., Dayan A., Lobo R.B., Garcia J.M., Smith L.C., 2001. Complete replacement of the mitochondrial genotype in a Bos indicus calf reconstructed by nuclear transfer to a Bos taurus oocyte. Genetics 158, 351-356

Michaels G.S., Hauswirth W.W., Laipis P.J., 1982. Mitochondrial DNA copy number in bovine oocytes and somatic cells. Develop. Biol. 94, 246-251

Miller F.J., Rosenfeldt F.L., Zhang C., Linnane A.W., Nagley P., 2003. Precise determination of mitochondrial DNA copy number in human skeletal and cardiac muscle by a PCR-based assay: lack of change of copy number with age. Nucl. Acid. Res. 31, E61

Moyes C.D., Battersby B.J., Leary S.C., 1998. Regulation of muscle mitochondrial design. J. Exp. Biol. 201, 299-307

Onishi A., Iwamoto M., Akita T., Mikawa S., Takeda K., Awata T., Hanada H., Perry A.C.F., 2000. Pig cloning by microinjection of fetal fibroblast nuclei. Science 289, 1188-1190

Ono Y., Shimozawa N., Ito M., Kono T., 2001. Cloned mice from fetal fibroblast cells arrested at metaphase by a serial nuclear transfer. Biol. Reprod. 64, 44-50

Park K.-W., Kühholzer B., Lai L., Machaty Z., Sun Q.-Y., Day B.N., Prather R.S., 2001. Development and expression of the green fluorescent protein in porcine embryos derived from nuclear transfer of transgenic granulosa-derived cells. Anim. Reprod. Sci. 68, 111-120

Pfanner N., Neupert W., 1990. The mitochondrial protein import apparatus. Ann. Rev. Biochem. 59, 331-353

Piko L., Taylor K.D., 1987. Amounts of mitochondrial DNA and abundance of some mitochondrial gene transcripts in early mouse embryos. Develop. Biol. 123, 364-374

Plante L., King W.A., 1994. Light and electron microscopic analysis of bovine embryos derived by in vitro and in vivo fertilization. J. Assist. Reprod. Genet. 11, 515-529

Plante Y., Schmutz S.M., Lang K.D.M., 1992. Restriction fragment length polymorphism in the mitochondrial DNA of cloned cattle. Theriogenology 38, 897-904

Polejaeva J.A., Chen S.-H., Vaught T.D., Page R.L., Mullins J., Ball S., Dai Y., Boone J., Walker S., Ayares D.L., Colman A., Campbell K.H.S., 2000. Cloned pigs produced by nuclear transfer from adult somatic cells. Nature 407, 86-90

Poulton J., 1995. Transmission of mtDNA: cracks in the bottleneck. Amer. J. Hum. Genet. 57, 224-226

Renard J.P., Zhou Q., LeBourhis D., Chavatte-Palmer P., Hue I., Heyman Y., Vignon X., 2002. Nuclear transfer technologies: between successes and doubts. Theriogenology 57, 203-222

Reynier P., May-Panloup P., Chretien M.F., Morgan C.J., Jean M., Savagner F., Barriere P., Malthiery Y., 2001. Mitochondrial DNA content affects the fertilizability of human oocytes. Mol. Hum. Reprod. 7, 425-429

Rideout III W.M., Eggan K., Jaenisch R., 2001. Nuclear cloning and epigenetic reprogramming of the genome. Science 293, 1093-1098

Roh S., Hwang W.-S., 2002. In vitro development of porcine parthenogenetic and cloned embryos: comparison of oocyte-activating techniques, various culture systems and nuclear transfer methods. Reprod. Fert. Develop. 14, 93-99 
Saccone C., Sbisa E., 1989. Organization and evolution of mitochondrial DNA in Metazoa. In: J.M. Tager, A. Azzi, S. Papa, F. Guerrieri (Editors). Organelles in Eukaryotic Cells. Molecular Structure and Interactions. Plenum Press, New York, pp. 127-142

Samiec M., 2004. Development of pig cloning studies: past, present and future. J. Anim. Feed Sci. $13,211-238$

Samiec M., Skrzyszowska M., Smorag Z., 2003a. Somatic cloning in pigs; effect of activation treatments. Theriogenology 59, 286 (Abstr.)

Samiec M., Skrzyszowska M., Smorag Z., 2003b. Effect of activation treatments on the in vitro developmental potential of porcine nuclear transfer embryos. Czech J. Anim. Sci. 48, 499-507

Schwartz M., Vissing J., 2002. Paternal inheritance of mitochondrial DNA. N. Eng. J. Med. 347, $576-580$

Schwartz M., Vissing J., 2003. New patterns of inheritance in mitochondrial disease. Biochem. Biophys. Res. Commun. 310, 247-251

Shitara H., Hayashi J., Takahama S., Kaneda H., Yonekawa H., 1998. Maternal inheritance of mouse mtDNA in interspecific hybrids: segregation of the leaked paternal mtDNA followed by the prevention of subsequent paternal leakage. Genetics 148, 851-857

Shitara H., Kaneda H., Sato A., Iwasaki K., Hayashi J., Taya C., Yonekawa H., 2001. Non-invasive visualisation of sperm mitochondria bahavior in transgenic mice with introduced green fluorescent protein (GFP). FEBS Lett. 500, 7-11

Skrzyszowska M., Samiec M., 2004. Somatic cloning in pigs; the use of live-DNA fluorescent dye YO-PRO-1 for detection of apoptosis in nuclear donor cells. In: Proceedings of $20^{\text {th }}$ Scientific Meeting of the European Embryo Transfer Association (A.E.T.E.). Lyon (France), p. 188

Skrzyszowska M., Samiec M., 2005. Production of porcine nuclear transfer embryos using fetal fibroblast cells analyzed on apoptosis. Proceedings of $31^{\text {st }}$ Annual Conference of the International Embryo Transfer Society (IETS), Copenhagen (Denmark). Reprod. Fertil. Develop. 17 (1, 2), 182-183

Skrzyszowska M., Samiec M., Smorag Z., 2003. In vitro developmental potential of porcine embryos reconstructed with cumulus cell nuclei: effect of culture conditions. In: Proceedings of $19^{\text {th }}$ Scientific Meeting of the European Embryo Transfer Association (A.E.T.E.). Rostock (Germany), p. 210

Skrzyszowska M., Shioya Y., Nagai T., Geshi M., Tokenouchi N., 2000. Development of cloned bovine embryos from nuclei of cumulus and muscle cell origin. Theriogenology 53, 244 (Abstr.)

Smeitink J., van der Heuvel L., DiMauro S., 2001. The genetics and pathology of oxidative phosphorylation. Nat. Rev. Genet. 2, 342-352

Smith L.C., Alcivar A.A., 1993. Cytoplasmic inheritance and its effects on development and performance. J. Reprod. Fert. 48, Suppl., 31-43

Smith L.C., Bordignon V., Garcia J.M., Meirelles F.V., 2000. Mitochondrial genotype segregation and effects during mammalian development: applications to biotechnology. Theriogenology 53, 35-46

Smith L.C., Bordignon V., Couto M.M., Garcia J.M., Yamazaki W., Meirelles F.V., 2002. Mitochondrial genotype segregation and the bottleneck. Reprod. BioMed. Online 4, 248-255

Steinborn R., Schinogl P., Wells D.N., Bergthaler A., Muller M., Brem G., 2002. Coexistence of Bos taurus and $B$. indicus mitochondrial DNAs in nuclear transfer-derived somatic cattle clones. Genetics 162, 823-829

Steinborn R., Schinogl P., Zakhartchenko V., Achmann R., Schernthaner W., Stojkovic M., Wolf E., Muller M., Brem G., 2000. Mitochondrial DNA heteroplasmy in cloned cattle produced by fetal and adult cell cloning. Nat. Genet. 25, 255-257

Steinborn R., Zakhartchenko V., Jelyazkov J., Klein D., WolfE., Muller M., Brem G., 1998a. Composition of parental mitochondrial DNA in cloned bovine embryos. FEBS Lett. 426, 352-356

Steinborn R., Zakhartchenko V., Wolf E., Muller M., Brem G., 1998b. Non-balanced mix of mitochondrial DNA in cloned cattle produced by cytoplast-blastomere fusion. FEBS Lett. 426, 357-361 
Steuerwald N., Barritt J.A., Adler R., Malter H., Schimmel T., Cohen J., Brenner C.A., 2000. Quantification of mtDNA in single oocytes, polar bodies and subcellular components by realtime rapid cycle fluorescence monitored PCR. Zygote 8, 209-215

St. John J., Lloyd R., Shourbagy S., 2004a. The potential risks of abnormal transmission of mtDNA through assisted reproductive technologies. Reprod. BioMed. Online 8, 34-44

St. John J.C., Lloyd R.E.I., Bowles E.J., Thomas E.C., Shourbagy S.El., 2004b. The consequences of nuclear transfer for mammalian foetal development and offspring survival. A mitochondrial DNA perspective. Reproduction 127, 631-641

Surani A., 2001. Reprogramming of genome function through epigenetic inheritance. Nature 414, $122-128$

Sutovsky P., 2004. Degradation of paternal mitochondria after fertilization: implications for heteroplasmy, assisted reproductive technologies and mtDNA inheritance. Reprod. BioMed. Online 8, 24-33

Sutovsky P., Moreno R.D., Ramalho-Santos J., Dominko T., Simerly C., Schatten G., 1999. Ubiquitin tag for sperm mitochondria. Nature 402, 371-372

Sutovsky P., Moreno R.D., Ramalho-Santos J., Dominko T., Simerly C., Schatten G., 2000. Ubiquitinated sperm mitochondria, selective proteolysis, and the regulation of mitochondrial inheritance in mammalian embryos. Biol. Reprod. 63, 582-590

Sutovsky P., Navara C.S., Schatten G., 1996. Fate of the sperm mitochondria, and the incorporation, conversion, and disassembly of the sperm tail structures during bovine fertilization. Biol. Reprod. 55, 1195-1205

Takeda K., Akagi S., Kaneyama K., Kojima T., Takahashi S., Imai H., Yamanaka M., Onishi A., Hanada H., 2003. Proliferation of donor mitochondrial DNA in nuclear transfer calves (Bos taurus) derived from cumulus cells. Mol. Reprod. Dev. 64, 429-437

Takeda K., Onishi A., Takahashi S., Kojima T., Hanada H., 1997. Genetic variants of bovine mitochondrial DNA D-loop region in Japanese Black, Japanese Brown and Holstein breeds. Anim. Sci. Technol. (Japan) 68, 1161-1165

Takeda K., Takahashi S., Onishi A., Goto Y., Miyazawa A., Imai H., 1999. Dominant distribution of mitochondrial DNA from recipient oocytes in bovine embryos and offspring after nuclear transfer. J. Reprod. Fertil. 116, 253-259

Trounce L., 2000. Genetic control of oxidative phosphorylation and experimental models of defects. Hum. Reprod. 15, Suppl. 2, 18-28

Van Blerkom J., 2004. Mitochondria in human oogenesis and preimplantation embryogenesis: engines of metabolism, ionic regulation and developmental competence. Reproduction 128, 269-280

Wakayama T., Perry A.C.F., Zuccotti M., Johnson K.R., Yanagimachi R., 1998. Full-term development of mice from enucleated oocytes injected with cumulus cell nuclei. Nature 394, 369-374

Wakayama T., Yanagimachi R., 2001. Effect of cytokinesis inhibitors, DMSO and the timing of oocyte activation on mouse cloning using cumulus cell nuclei. Reproduction 122, 49-60

Wells D.N., Misica P.M., Tervit H.R., 1999. Production of cloned calves following nuclear transfer with cultured adult mural granulosa cells. Biol. Reprod. 60, 996-1005

Wilmut I., Schnieke A.E., McWhir J., Kind A.J., Campbell K.H.S., 1997. Viable offspring derived from fetal and adult mammalian cells. Nature 385, 810-813

Yamazaki Y., Meirelles F.V., Bordignon V., Garcia J.M., Smith L.C., 1999. Effect of mitochondrial DNA on developmental outcome of cytoplast-reconstructed mouse zygotes. Arq. Fac. Vet. UFRGS 27, 299 (Abstr.)

Yin X.J., Tani T., Yonemura I., Kawakami M., Miyamoto K., Hasegawa R., Kato Y., Tsunoda Y., 2002. Production of cloned pigs from adult somatic cells by chemically assisted removal of maternal chromosomes. Biol. Reprod. 67, 442-446 


\section{STRESZCZENIE}

\section{Rola genomu mitochondrialnego (mtDNA) w klonowaniu somatycznym i zarodkowym ssaków}

Mitochondria są półautonomicznymi organellami, o własnym materiale genetycznym w formie dwuniciowych (heliksowo zwiniętych), kolistych cząsteczek DNA (mtDNA) o długości około 16300 do 16500 par zasad (pz). W mitochondrialnym DNA zakodowana jest informacja o strukturze 13 białek, 22 cząsteczek tRNA oraz 2 cząsteczek rRNA. W biogenezę i funkcje cytofizjologiczne mitochondriów zaangażowanych jest aż $95 \%$ białek, będących produktami cytoplazmatycznego systemu translacji, kodowanego przez jądrowy DNA. Łączna pula kopii genomu mitochondrialnego $\mathrm{w}$ typowej komórce somatycznej ssaka wynosi $\mathrm{w}$ przybliżeniu $2-5 \times 10^{3}$, podczas gdy liczba cząsteczek mtDNA w dojrzałym oocycie (w stadium metafazy II podziału mejotycznego) dochodzi do $1.6 \times 10^{5}$ u myszy, $2.5 \times 10^{5}$ u bydła oraz $3-8 \times 10^{5}$ u człowieka. W procedurze klonowania somatycznego lub zarodkowego mitochondria komórekdawców jąder transplantowane są wraz z jądrowym aparatem genetycznym do cytoplazmy enukleowanych oocytów-biorców (ooplastów). Dlatego też, zrekonstruowany zarodek klonalny, będący z cytologicznego punktu widzenia hybrydą cytoplazmatyczną (cybryda), jest nośnikiem genomu pochodzenia mitochondrialnego, zarówno oocytarnego (matecznego), jak i egzogennego (wprowadzonego z komórką-dawcą jądra). W przypadku sklonowanych zwierząt, mitochondria są dziedziczone pierwotnie wraz $\mathrm{z}$ materiałem ooplazmatycznym. Z kolei mitochondria pochodzące z komórek-dawców jąder ulegają prawdopodobnie gwałtownej eliminacji z cytoplazmy komórek zarodkowych podczas kilku pierwszych podziałów bruzdkowania, a ich obecność w komórkach blastocyst klonalnych jest trudna do wykrycia technikami biologii molekularnej. Zachodzący w przedimplantacyjnej fazie rozwoju proces selektywnej segregacji genomu mitochondrialnego komórek-dawców jąder prowadzi stopniowo do powstania komórkowej homoplazmii mtDNA w rekonstytuowanych zarodkach. Jedynie w kilku przypadkach, trwała hybrydyzacja (synergistyczne funkcjonowanie) mtDNA komórek-dawców i biorców jąder, była możliwa do zmonitorowania w pre- i postnatalnym okresie rozwoju osobników klonalnych (tzw. heteroplazmia mtDNA). Warto również dodać, że mówiąc o klonowaniu, zarówno zarodków jak i zwierząt dorosłych, zapomina się często o współistnieniu w hybrydowym środowisku cytoplazmatycznym zygot klonalnych mitochondrialnego aparatu genetycznego pochodzenia matecznego i allogenicznego (z komórek zarodkowych lub somatycznych), który zawiera wprawdzie niewielką (około 0,01\%) część informacji dziedzicznej komórki, ale różni się od informacji zapisanej w sekwencji nukleotydów DNA jądrowego, stanowiącego aż 99,99\% genomu komórki. W tym aspekcie, transplantacja jądra dawcy do oocytu pochodzącego od innego osobnika prowadzi do powstania hybryd jądrowocytoplazmatycznych majcych heterogeniczne kopie mtDNA, co oczywiście może mieć pewien wpływ na identyczność genotypową i fenotypową uzyskiwanego w wyniku klonowania potomstwa. „Idealny” klon można uzyskać tylko wówczas, gdy jądro komórki-dawcy zostanie wprowadzone do oocytu pochodzącego od tego samego osobnika. „Idealnymi” klonami ssaków mogą być zatem jedynie klony samic, których genotyp mitochondrialny (mitotyp) powinien zawierać całkowicie homogenny wzorzec sekwencji kodujących i regulatorowych wszystkich kopii mtDNA komórek linii somatycznej i płciowej, w następstwie autogenicznego (autologicznego) źródła jądrowego i mitochondrialnego aparatu genetycznego w cybrydowych liniach komórkowych. 